\title{
IMPLEMENTASI PERAWATAN BERPUSAT PADA KELUARGA DI RUANG PEDIATRIC INTENSIVE CARE UNIT
}

\author{
Andra Saferi Wijaya ${ }^{1}$, Fitri Haryanti ${ }^{2}$, Indria Laksmi Gamayanti ${ }^{3}$ \\ 1. Politeknik Kesehatan Kementerian Kesehatan Bengkulu \\ 2. Fakultas Kedokteran Kesehatan Masyarakat dan Keperawatan Universitas Gadjah Mada \\ Yogyakarta \\ 3. Instalasi Kesehatan Anak RSUP Dr. Sardjito Yogyakarta
}

andrasaferi@gmail.com

\begin{abstract}
Child treatment in Pediatric Intensive Care Unit (PICU) is a total treatment conducted by health workers, so the family involvement in this room is limited. Family involvement is an important component of Family-Centered Care. The purpose of this study was to explore Family-centered Care in Pediatric Intensive Care Units. This study used qualitative phenomenology. Then, it conducted with purposive sampling to twelve participants that consist of parents, nurses, and physicians. In this research, Data Collected by in-depth interviews, observation, and study document. Study verbatim of the interview was Colaizzi analyzed manually using Open Code Software. Result of themes were (1) Value of parents and child inPediatric Intensive Care Units, (2) parents and nurses perception, (3) the implementation, (4) benefits, (5) challenges, (6) the expectation of Family-Centered Care implementation in Pediatric Intensive Care Unit. The restricting rules in Pediatric Intensive Care Unit caused families could not participate in the treatment child in Pediatric Intensive Care Unit. Furthermore, the recommendation of this research is needed easy access for families involving the treatment of their child in Pediatric Intensive Care Unit.
\end{abstract}

Keywords: Family Centered Care, child, critical, pediatric, intensive care, qualitative study.

\begin{abstract}
Abstrak: Perawatan anak di PICU merupakan perawatan total yang dilakukan oleh petugas kesehatan, sehingga keterlibatan keluarga di ruangan sangat terbatas. Keterlibatan keluarga merupakan kompenen penting dalam perawatan berpusat pada keluarga. Penelitian ini bertujuan mengeksplorasi perawatan berpusat pada keluarga (PBK) di PICU. Penelitian kualitatif fenomenologi dilakukan dengan teknik penentuan sampel secaraporpusive sampling sebanyak 12 orang terdiri dari orang tua, perawat, dan dokter.Pengumpulan data dilakukan dengan wawancara mendalam, observasi, dan studi dokumentasi. Transkrip verbatim wawancara dianalisis manual menurut Colaizzi menggunakan software OpenCode. Tema yang dihasilkan yaitu: (1) makna orang tuadengan anak di PICU, (2) persepsiorang tua dan perawat, (3)penerapan, (4) manfaat, (5) tantangan, dan (6) harapan penerapan perawatan berpusat pada keluarga di PICU. Ketatnya peraturan di PICU menyebabkan keluarga tidak dapat berpartisipasi merawat anak di PICU.Rekomendasi penelitian ini perlu adanya akses yang mudah bagi keluarga untuk terlibat dalam perawatan anak di PICU.
\end{abstract}

Kata kunci: perawatan berpusat pada keluarga, anak, kritis, PICU, studi kualitatif

Pengalaman orang tua ketika anak menegangkan dan sulit(1,2). Menurut
menjalani perawatan di ruang perawatan
kritis merupakan pengalaman yang


keselamatan anak dan terpasangnya alatalat penunjang pada anaknya. Kondisi anak yang dirawat inap karena penyakit kritis dapat mempengaruhi setiap anggota keluarga(2,3). Pengaruh tersebut disebabkan perubahan peran orangtua dan masalah yang dihadapi seperti, adanya masalah psikologis, tidak berdaya, tidak tahu cara merawat anak yang sakit, dan masalah finansial.

Berbagai intervensi telah dilakukan untuk mengurangi stres orang tua,namun belum menujukan hasil yang signifikan. Intervensi tersebut diantaranya adalah, pemberian pendidikan kesehatan dan penyediaan informasi yang cukup tekait kondisi anak serta prosedur perawatan yang dijalani, pemenuhan kebutuhan perkembangan anak dan keluarga, memperhatikan koping anak dan orang tua, serta meningkatkan dukungan kepada keluarga (5-7). Prinsip intervensi tersebut merupakan bagian dari elemen perawatan berpusat pada keluarga. Smith et al menyatakan bahwa PBK dapat mengurangi stres pada orang tua dengan anak yang dirawat dengan kondisi kritis, karena orang tua ikut terlibat dalam perawatan anak.

Ruang PICU memiliki peraturan yang membatasi keterlibatan orang tua, misalnya jam kunjungan terbatas dan lingkungan perawatan yang kompleks, sehingga anggota keluarga tidak dapat bebas masuk ke ruang perawatan. Peran keluarga yang sangat terbatas, karena kondisi ruangan tertutup, steril, pasien yang membutuhkan perawatan yang lebih ekstra, dan waktu untuk berkunjung terbatas, berakibat pada akses komunikasi dan pelibatan orang tua dalam perawatan anak berkurang, sehingga pelaksanaan prinsip perawatan anak berdasarkan konsep perawatan berpusat pada keluarga $(\mathrm{PBK})$ di ruang perawatan intensif belum dapat dilaksanakan secara optimal.

Hasil observasi oleh peneliti pada saat studi pendahuluan di ruang PICU, menunjukkan bahwa orang tua dengan anak yang dirawat di ruang PICU lebih banyak menunggu di luar ruangan dan mengalami keterbatasan pertisipasi dalam merawat anak.Kondisi tersebut bertentangan dengan prinsip perawatan berpusat pada keluarga yang merekomendasikan bahwa orang tua harus memiliki akses 24 jam untuk merawat anaknya dan orang tua diberikan fasilitas yang cukup untuk mencapai tujuan prinsip ini. Rumah sakit di negara-negara berkembang seringberanggapan bahwa telah mempraktikan perawatan berpusat pada keluarga(PBK), dengan alasan orang tua telah banyak dilibatkan dalam perawatan. Namun, hal tersebut sebenarnya terjadi akibat kekurangan sumber daya dan tenaga kesehatan di rumah sakit. Penelitian terkait PBK di Indonesia belum banyak dilaporkan, sedangkan manfaat penerapan PBK telah banyak dibuktikan. Indonesia 
merupakan salah satu negara berkembang yang memiliki kultur budaya dimana masyarakat terbiasa terlibat dalam perawatan salah satu anggota keluarga yang sakit. Upaya untuk memahami tentang penerapan PBK di ruang PICU dapat dilakukan dengan melakukan eksplorasi melalui persepsi pasien dan perawat tentang PBK.

\section{BAHAN DAN CARA KERJA}

Rancangan penelitian ini adalah kualitatif dengan pendekatan fenomenologi deskriptif. Peneliti memilihmetode fenomenologi karena, memungkinkan untuk melakukan eksplorasi mendalam dan mendeskripsikan suatu fenomena yang sedang diteliti dengan membebaskan diri peneliti dari penilaian awal. Penelitian ini menggali pengalaman orang tua dan perawat dalam pemberian asuhan keperawatan dengan pendekatan PBKGuba \& Lincoln, (1981) cit. (Alwasilah, 2012).

Penelitian ini dilakukan di ruang perawatan intensif anak (PICU) RSUP Dr. Sardjito Yogyakarta. Penentuan partisipan dipilih dengan menggunakan metode porpusive sampling. Proses pemilihan partisipan berdasarkan pertimbangan peneliti mengenai individu yang memiliki kekayaan informasi serta dapat memberikan informasi secara bermakna untuk tercapai tujuan peneliti. Partisipan berasal dari kelompok orang tua dan kelompok perawat. Kriteria inklusi pada kelompok orang tua adalah Orang tua yang bersedia menjadi partisipan dalam penelitian dengan menandatangani informed consent; Orang tua yang menunggui anaknya; Orang tua mampu berkomunikasi dalam bahasa Indonesia; Orang tua yang anak dirawat di ruang PICU lebih dari 3 hari. Kriteria ekslusi adalah orang tua dengan anak dirawat diduga akibat tindakan kekerasan. Kriteria inklusi untuk partisipan dari kelompok perawat yaitu: Pendidikan terakhir minimal D3; Perawat pelaksana yang bertugas di ruang PICU RSUP Dr. Sardjito lebih dari 3 tahun, Bersedia menjadi partisipan dengan mengisi lembar informed consent. Sedangkan kriteri ekslusi adalah perawat yang sedang magang atau cuti selama periode penelitian dilakukan.

Kegiatan pengumpulan data dilakukan selama tiga bulan. Partisipan berjumlah 10 orang, yang terdiri dari lima orang tua pasien dan lima perawat dengan berdasarkan saturasi data yang telah dicapai oleh peneliti. Peneliti juga melakukan wawancara dengan dokter residen spesialis anak untuk mendapatkan data yang komprehensif serta sebagai triangulasi sumber.

Instrumen penelitian adalah peneliti sendiri, dengan menggunakan pedoman wawancara dalam pengumpulan data. Wawancara mendalam dilengkapi field 
notes. Observasi dilakukan oleh penliti untuk menjaga thrustworthiness data penelitian. Wawancara direkam dengan alat perekam digital dan disimpan dalam bentuk rekaman audio dan tranksrip verbatim. Data dianalisis menggunakan metode Colaizzi dengan bantuan software OpenCode versi 4.0.2.3

Penelitian ini telah mendapatkan kelayakan etik penelitian dari Komite Etik Fakultas Kedokteran UGM. Penelitian dilakukan dengan memenuhi kaidah etik yang terdiri dari, otonomi dengan lembar informed consent, menghormati privasi dan kerahasian partisipan berdasarkan azaz keadilan, serta tidak menimbulkan risiko bagi pasien dan partisipan.

\section{HASIL}

Karakteristik partisipan penelitian ini adalah 5 orang tua pasien yang terdiri dari 4 orang ibu pasien dan 1 orang ayah pasien dengan usia berkisar antara 20-45 tahun, sebagian besar dari suku Jawa. Latar belakang pendidikan sebagian besar pendidikan menengah dan sebagiannya lagi pendidikan tinggi. Pekerjaan partisipan sebagian besar ibu rumah tangga. Partisipan dari kelompok perawat sebanyak 5 orang, terdiri dari perawat pelaksana, perawat penanggung jawab jaga, perawat primer, dan kepala ruangan dengan usia berkisar antara 30-50 tahun, sebagian besar memiliki pengalaman kerja di PICU di atas
12 tahun. Latar belakang pendidikan partisipan perawat adalah, 2 orang diploma keperawatan dan 3 orang S1 keperawatan. Perawat diploma belum pernah terpapar informasi mengenai PBK, dari 2 partisipan dokter residen spesialis anak sebagai triangulasi sumber, dengan lama pengalaman klinis di ruang PICU selama 3 bulan, hanya 1 orang yang telah terpapar informasi mengenai PBK.

Hasil Content analysis partisipan ke-1 sampai ke-12 (R1-R12), didapatkan 6 tema.

\section{Makna orang tua dalam perawatan anak di ruang PICU}

Tema ini menggambarkan bagaimana perasaan orang tuadengan anak yang dirawat di PICU. Orang tua mengatakan ingin terlibat dalam perawat anak, karena mereka ingin selalu berada didekat anak.

"Yo agak gelisah lah mas. Penginnya kan yo nungguin lihat toh.gimana"(Orang tua pasien $\mathrm{R} 1$ )

Partisipan orang tua merasa cemas,gelisah, dan bersalah dengan kondisi anak yang dirawat di PICU.

“..liat anak kita. Jangankan masuk PICU, digigit nyamuk aja kita gak tega... masuk PICU dikasih infus, ventilator, operasi, suntik sana, suntik sini, perasaan kita ya... gak tau saya. Campur aduklah sedih, perasaan kita juga merasa bersalah, kok anaknya bisa seperti itu..."(Orang tua pasien R4). 
Persepsi orang tua dan perawat tentang PBK di ruang PICU

Tema ini terdiri dari 2 sub tema, yaitu pemahaman tentang pengertian PBK dan pemahaman tentang konsep dasar PBK. Perawat mempersepsipkan pengertian PBK adalah orang tua merupakan aspek penting dalam perawatan anak, hubungan anak dan keluarga tidak boleh terputus dalam memberikan asuhan keperawatan anak.

"Setidaknyakan hubungan anak dan orang tua tidak terputus trus bisa, anaknya bisa tenang kan bisa.." (Perawat R7)

PBK juga merupakan adanya pelibatan dan kerjasama petugas dan orang tua merawat anak.

"Perawatan berfokus pada keluarga itu bagaimana ee...dalam orang. jadiorang tua itu ikut terlibat dalam perawatan pasien atau si anak. Jadi ee...istilahnya bekerjasama antara perawat dan keluarga dalam merawat si anak. Itu perawatan berfokus pada keluarga.." (Perawat R8)

Pemahaman tentang konsep PBK dipersepsikan partisipan dengan menghormati keluarga dalam perawatan anak, yaitu dengan mengikuti keyakinan dan nilai yang terdapat dalam keluarga.

"Misalnya ee...tidak boleh potong kuku saat sakit. Kita tidak memotong kuku, kita ikuti. Kemudian orang tua misalnya punya keyakinan mbak ini minta tolong tolong air putihnya didoakan. Kita berikan sesuai dia.. tapi itu air putih." (Perawat R6)

Terjalin kerjasama antara petugas kesehatan dengan orang tua dalam pengambilan keputusan.

"Kalau pengambilan keputusan kita semua disini ke orang tua.(Perawat R9)

\section{Penerapan PBK di ruang PICU}

Temuan dalam penelitian ini menunjukan bahwa sudah terlaksana PBK di ruang PICU dibuktikan dengan keterlibatan keluarga dan berbagi informasi tentang perawatan anak

"Perawat sama dokter kita operan kita baringkan sesuai tempatnya kita pasang monitor semuanya, kalau anak rewel... Nah..rewel. Rewel walaupun mau ada tindakan orang tua dipanggil." (Perawat R6)

Perawat tersebut menjelaskan bahwa keterlibatan orang tua dalam menenangkan anak saat perawatan.Orang tua menjelaskan sudah berpartisipasi dalam perawatan anak, walaupun belum optimal.

"Partisipasinya ya sedikit sekali, ya misalnya dia tidur miring ya, kita bikin lurus seperti itu ya hal-hal kecil yang tidak terlihat perawat ya, kalau ada tai matanya kita bersihkan trus misalnya selang infus tertarik ya kita benerin naikin ke atas. Ya paling itu mas..." (Orang tua R4)

Berbagi informasi telah dilakukan di PICU, berdasarkan penjelasan dari perawat 
mereka telah menjelaskan peran yang dapat dilakukan orang tua di ruangan, penyampaian kondisi dan pengobatan anak.

"Keterlibatan keluarga diruangan ini yang bisa dilakukan. Misalnya untuk perawatan di PICU itukan kalau mungkin bapak ibu taunya cuma perawat atau dokter tapi sekarang gak kita harus melibatkan juga keluarga. Ber..apa, bekerja sama bareng-bareng untuk melakukan perawatan sama adek seperti itu. " (Perawat R6)

Partisipan orang tua mengatakan bahwa penyampaian informasi dari petugas kesehatan kurang dapat dimengerti oleh mereka.

"Menurut saya dia itu penjelasanya itu kurang jelas, dia bilang itu... dia menjelaskan cuma fungsinya aja, dan bentuknya." (Orang tua R4)

\section{Manfaat Penerapan PBK di ruang PICU}

Orang tua pasien mengatakan kehadiran orang tua dapat memberikan kasih sayang bagi anak.Bagi orang tua, mendampingi anak secara langsung membuat perasaan mereka lebih tenang, tidak cemas, dan senang membantu merawat anak.

"Ya manfaatnya, kita tahu perkembangan anak. Orang tua juga tidak terlalu khawatir, kalau kita masuk itu bisa tahu perkembangannya dia, kita bisa tenang juga ya, itu manfaatnya, kita tidak terlalu tegang gitu.” (Orang tua R4)
Manfaat yang dirasakan oleh petugas kesehatan adalah, orang tua dapat membatu mereka dalam merawat anak diruangan, seperti memantau monitor anak, dan menenangkan anak saat dilakukan tindakan.

"Misalnya pasien itu sering periodik apnue, periodik apneu gitu ya, memang orang tua kadang kala kita melibatkan, kalau itu memang.. kita sering libatkan. Ibu bisa lihat monitor itu, kan dia tau yang paling atas itu denyut nadi kemudian yang kedua respirasi itu kita kasih tau." (Perawat R6)

\section{Tantangan pelaksanaan PBK di Ruang PICU}

Ruang PICU merupakan ruang kritis dengan peratuaran yang ketat, sehingga membatasi kehadirian keluarga di ruangan. Selain itu, petugas kesehatan juga mengatakan kurang percaya diri dalam melakukan tindakan saat ada orang tua di dekat pasien.

"Karena kita mau melakukan tindakan gitu kan, terkadang kalau ada keluarga itu kan menurunkan rasa kayak percaya diri, kan ada to wah jadi tambah kayak grogi gitu kan ada.” (Perawat R9)

Sebagian besar orang tuatidak berani terlibat dalam perawatan anak di PICU.Orang tualebih memilih untuk tidak ikut campur dalam perawatan anak demi kebaikan anak. 
"Soalnya saya kalau ikut terjun kayak gitu takut mas sama petugasnya sini” (Orang tua R1)

Kurangnya dukungan dari RS juga menghambat penerapan PBK di PICU.

"Kalau menurut saya, dukungannya kurang sekali ya. Kemaren saat pertama kali saya datang, saya bilang kita tidak boleh masuk ya dok? Trus ada ruang tunggunya tidak, gak ada kata dokternya." (Orang tua R4)

$$
\text { "sebenarnya ruang tunggu }
$$
kurangkan kalau sebenarnya kalau kayak rumah sakit kayak PICU itu kalau harusnya, kalau ada e... kayak nggak boleh, paling nggak kayak jadi ndelok (melihat) kayak ada ruang kayak kaca atau apa gitu, jadinya kalau disitu kan terlalu jauh untuk melihat anak." (Perawat R9)

\section{Harapan Pelaksanaan PBK di Ruang PICU}

Keluarga berharap adanya ruang tunggu khusus untuk keluarga pasien PICU dandesain ruang perawatan dengan kaca,supaya keluarga dapat melihat anak secara langsung.

"Iya namanya ruang tunggu Baby show, jadi ruang PICU nanti masuk ada kacanya dia... itu kedap suara ruangannya,jadi suster atau dokter merawat anak-anak itu, gak kedengaran suaranya, tapi kita bisa itu anak saya, jadi kalau ada yang jenguk jadi enak... itu anak saya itu sana..di doakan, bisa tahu kondisinya, fisiknya, walau tidak tahu apa penyakitnya setidaknya dapat melihat kondisinya gitu." (Orangtua R4)

Temuan dari data tersebut di didukung oleh pendapat dari dokter spesealis anak sebagai dokter penanggung jawab di ruangan yang menyatakan bahwa seharusnya ruang khusus seperti ini memang hendaknya ada ruang tunggu dengan kaca besar yang terhubung dengan ruang perawatan anak. "seharusnya ada sih.. ruangan seperti itu, namn karena kondisi rumah sakit belum mendukung, jadi ya hanya ada ruangan tunggu bersama seperti itu (menunjukkan ruang tunggu)" (Dokter $\mathrm{R} 12$, baris 258-260)

Tenaga perawat dan dokter yang merawat anak di ruang PICU juga mengatakan hal serupa bahwa hendaknya ada ruang khsus untuk keluarga menunggu, namun tetap dapa melihat anak dirawat di ruangan. Dokter juga berharap orang tua lebih meluangkan waktu berpartisipasi dalam merawat anaknya walaupun kondisi anak tidak sadar, sehingga orang mengetahui apa saja yang di butuhkan selama perawatan anak.

"Dari keluarga itu akan mengetahui apa saja yang terjadi pada anaknya.Aaa... perawatan apa saja yang dibutuhkan, kemudian apa yang harus dilakukan oleh orang tuanya." (Dokter R12, baris 261264) 
"Ya..kalau misalnya untuk manfaat di orang tuanya ya jadi orang tua itu merasa bahwa apa dia itu ee...apa ya, masih merasa bahwa oh... saya, saya tuh orang tuanya gitu loh. Saya di... di istilahnya diwongkan itu apa ya? Dihargai saya ikut terlibat ke anak.Jadi seperti itu tidak memisahkan anak dengan orangtua." (Perawat R8, baris 568-575).

\section{PEMBAHASAN}

Respon emosional yang ditunjukan orangtua dengan anak yang dirawat di ruang PICU pada umumnya merasakan kecemasan, kekhawatiran, kesedihan, gelisah, dan perasaan bersalah. Beberapa penelitian menjelaskan sebagian besar orang tua mengalami stres emosional ketika anak mereka dirawat di ruang PICU (1517). Kecemasan dan kekhawatiran orang tua disebabkan prosedur tindakan pada anak, penurunan kondisi anak yang drastis, lingkungan ruangan PICU, dan berbagai peralatan medis yang terpasang pada anak.Colville et al menyebutkan bahwa, tingkat stres orang tuayang tinggi disebabkan karena menyaksikan prosedur medis dan kondisi anak.

Temuan dari penelitian ini terlihat orang tua tidak semangat dan tampak kelelahan saat diwawancari oleh peneliti. Penelitian yang dilakukan oleh Berube et al(2014) juga menjelaskankeluarga mengalami kelelahan fisik dan mental saat menunggui anak di rumah sakit. Pendekatan intervensi keperawatan hendaknya juga memperhatikan respon emosional keluarga dan memperhatikan kebutuhan orang tua.Perawat mengatakan bahwa mereka telah melakukan pendekatan kepada keluarga pasien, dengan menggali perasaan dan memberikan semangat kepada orang tua untuk selalu mendoakan anak.Ruang tunggu bagi keluarga pasien juga tersedia di depan ruang PICU. Smith et al (2007) merekomendasikan agar orangtua memiliki akses berkelanjutan untuk mendampingi anak, dengan diterapkan kebijakanrooming in sebagai bentuk penerapan PBK.

Temuan penelitian ini menunjukan bahwa sebagian besar partisipan perawat telah terpapar informasi mengenai PBK dan mampu mendefinisikannya. Partisipan orang tua mampu menggambarkan keterlibatanya dalam perawatan anak.

Partisipan perawat mempersepsikan PBK sebagai proses perawatan dengan tidak memisahkan orang tua dan anak, melibatkan keluarga dalam perawatan anak, kemitraan dalam perawatan anak,serta perawatan yang holistik. Memperhatikan aspek psikologis pada anak yaitu, memandang kedekatan emosional antara anak dan orang tuasebagai hal yang penting dalam perawatan anak, peka terhadap ekspresi, dan memperhatikan kebutuhan 
kasih sayang yang diperlukan anak dari keluarga.

Partisipan orang tua mendeskripsikan PBK dengan hadir di ruangan mendampingi anak, adanya keterlibatan dan partisipasi keluarga, serta dukungan keluarga dalam perawatan anak. Hasil penelitian serupa oleh Stuart \&Melling (2014), bahwa PBK menurut orang tua adalah mempertimbangkan keluarga dalam perawatan anak dan menjadikan keluarga sebagai prioritas perawatan. Temuan penelitian ini menunjukkan bahwa orang tuaingin hadir dan berada disamping anak untuk mendoakan dan berinteraksi dengan anak. Serupa dengan penelitian Ames et al., (2011) dan Maxton, (2008)orang tua aktif mencari cara untuk berinteraksi dan hadir dalam perawatan anak mereka di PICU, serta ingin bersama anak dalam semua keadaan. Kehadiran orang tua di ruangan memberi ketenangan bagi orang tua, orang tua mengetahui prosedur tindakan yang dilakukan pada anak (Dingeman et al., 2007). Partisipasi orang tua dalam perawatan anak di PICU dapat mengurangi kecemasan orang tua dan anak. Hal ini menurut peneliti karena seyogyanya perawat utama dari anak adalah orang tuanya sendiri, ada hubungan batin yang kuat antara orang tua dan anak yang memberikan dukungan emosional dalam kesembuhan anak.
Penyedia layanan kesehatan harus berkerjasama dengan keluarga dalam melakukan asuhan keperawatan pada anak. Bentuk kerjasama tersebut dapat berupa pengambilan keputusan terkait pengobatan anak (26). Hal ini sejalan dengan pendapat Ames et al., (2011) dalam penelitiannya menjelaskan bahwa partisipan orangtua aktif mencari cara untuk berinteraksi, apa yang dapat dilakukan oleh orang tua terkait pengobatan anak dan hadir dalam perawatan anak mereka di PICU. Dijelaskan pada penelitian tersebut tiga cara yang dilakukan orangtua untuk berpartisipasi dalam perawatan anak mereka yaitu dengan berada disamping anak dan memberikan kenyamanan, ikut aktif dalam perawatan anak, serta memberikan penjelasan dan jaminan kepada anak mereka. Hal ini memiliki kesamaan dari hasil penelitian yang ditemukan oleh peneliti, partisipan orangtua dalam penelitian tersebut mengungkapkan mereka hanya ingin hadir dan berada disamping anak untuk mendoakan anak, dan berinteraksi dengan anak mereka. Walaupun anak dalam kondisi tidak sadar, orangtua meyakini bahwa anak merasakan kehadiran mereka di dekatnya.

Keterlibatan keluarga dalam perawatan anak di PICU dapat dilakukan dengan membantu perawat dalam menenangkan anak, memenuhi kebutuhan 
ADL, dan memberikan dukungan emosional serta spiritual bagi anak. Keberadaan orang tua disamping anak merupakan hal yang penting untuk memberikan dukungan emosional seperti dengan sentuhan, mengajak anak mengobrol, dan mendoakan anak (Rennick et al., 2011).

Tantangan penerapan PBK di ruang PICU berupa anggapan bahwa PICU adalah ruangan khusus yang berbeda dengan ruangan lain, banyaknya peraturan yang membatasi keluarga, dan kekhawatiran petugas kesehatan terhadap resiko penyebaran infeksi. Meert et al., (2013) dan Frazier et al., (2010) juga menemukan bahwa PBK sulit diterapkan di PICU karena kekhawatiran potensi penyebaran infeksi, pelanggaran privasi pasien, trauma orang tua dan saudara kandung pasien, kendala waktu, dan terbatasnya ruangan. Stigma orang tuayang tidak mau terlibat dalam perawatan karena takut salah dan membahayakan anak, serta takut kepada petugas,dapat menghambat penerapan PBK.

Petugas kesehatan hendaknya memberikan pendidikan kesehatan yang sesuai, sehingga keluarga memiliki keberanian untuk berperan serta dalam perawatan anak. Temuan dari beberapa penelitian mengatakan bahwa orang tua ingin selalu berada disamping anak saat perawatan (Ames et al., 2011; Dingeman et al., 2007; Maxton 2008). Hasil penelitian ini menunjukkan bahwa tidak semua orang tua selalu menginginkan untuk berada di samping anak saat tindakan. Sebagian partisipan orang tua lebih memilih untuk meninggalkan ruangan saat tindakan, terutama pada saat dilakukan prosedur invasif karena mereka merasa tidak tega melihat anaknya.

Harapan terkait pelaksanaan PBK di ruang PICU adalah adanya dukungan bagi keluarga untuk terlibat dalam perawatan anak. Perawat dan orang tua pasien berpendapat masih kurangnya dukungan fasilitas dan kebijakan yang memberikan keleluasaan keluarga berpartisipasi dalam perawatan anak. Ruang PICU hendaknya didesain sesuai dengan kebutuhan keluarga. Ruangan harusnya dapat memfasilitasi keluarga untuk melihat pasien secara langsung tanpa perlu masuk kedalam ruangan. Komunikasi antara petugas kesehatan dan keluarga harus lebih ditingkatkan. Komunikasi yang baik antara petugas dengan keluarga menghasilkan tingkat kepuasaan keluarga terhadap pelayanan (Thompson et al., 2012)

\section{KESIMPULAN}

Kehadiran orang tua saat perawatan merupakan koping keluarga untuk mengurangi kecemasan terhadap kondisi anak. Kehadiran keluarga merupakan bagian dari konsep PBK. Orang 
tuamempersepsikan PBK dengan memberikan dukungan doa bagi kesembuhan anak.PBK bermanfaat bagi orang tua dan perawat,yaitu mengurangi kecemasan orang tua, membantu perawat dalam mengawasi anak, dan memberikan respon positif bagi anak yang dirawat.

Tantangan penerapan PBK di PICU adalah kurangnya dukungan fasilitas, ruangan PICU merupakan ruangan khusus dan steril, perawat kurang percaya diri dan tidak nyaman dengan kehadiran keluarga

\section{DAFTAR RUJUKAN}

Ames, K.E., Rennick, J.E. \& Baillargeon, S., 2011 b. A qualitative interpretive study exploring parents' perception of the parental role in the paediatric intensive care unit. Intensive \& critical care nursing: the official journal of the British Association of Critical Care Nurses, 27(3), pp.143-50. Available at: http://www.sciencedirect.com/science/article/ pii/S0964339711000279

[Accessed December 1, 2014].

Denzin, N.K., \& Lincoln, Y.S. (2005).The discipline and practice of qualitative research. In The Sage Handbook of Qualitative Research (Denzin, N. and Lincoln, Y. eds.). Thousand Oaks CA: Sage Publication

Majdalani MN, Doumit MAA, Rahi AC. The Lived Experience of Parents of Children Admitted to the Pediatric Intensive Care Unit in Lebanon. Int J Nurs Stud. 2014;51:217-25.

Perry S e., Hockenberry MJ, Lowdermilk DL, Wilson D. Maternal child Nursing Care. 5th ed. Cashion K, Alden KR, editors. Elsevier Inc.; 2014.

Balluffi A, Kassam-Adams N, Kazak A, Tucker M, Dominguez T, Helfaer M. Traumatic Stress in Parents of Children Admitted to The Pediatric Intensive Care Unit. Pediatr Crit Care Med [Internet]. 2004 Nov [cited 2014 Dec 1];5(6):547-53. Available from: http://www.scopus.com/inward/record.url?ei $\mathrm{d}=2$-s2.021644474956\&partnerID=tZOtx3y1

Ames KE, Rennick JE, Baillargeon S. A Qualitative Interpretive Study Exploring Parents' Perception of the Parental Role in the saat tindakan pada anak. Pelayanan kesehatan hendaknya memfasilitasi keluarga untuk berpartisipasi dalam merawat anak seperti kebebasan keluarga untuk menunggui anak di PICU. Hasil penelitian menurut partisipan dokter spesialis anak selain dukungan fasilitas tantangan penerapan PBK di ruang PICU adalah kebijakan dari rumah sakit itu sendiri dalam penyedian fasilitas untuk penerapa PBK.

Paediatric Intensive Care Unit. Intensive Crit Care Nurs [Internet]. Elsevier Ltd; 2011;27(3):143-50. Available from: http://linkinghub.elsevier.com/retrieve/pii/S0 964339711000279

Ashley M. Frisch, Arlene Johnson, Shirley Timmons CW. Nurse Practitioner Role in Preparing Families for Pediatric Outpatient Surgery. Pediatr Nurs. 2010;36(1):41-7. Hockenberry MJ, Wilson D. Wong's Essentials of Pediatric Nursing. 9th ed. St. Louis: Elsevier Inc.; 2013.

Litke J, Pikulska A, Wegner T. Management of perioperative stress in children and parents. Part I - The preoperative period. Anaesthesiol Intensive Ther [Internet]. 2012;44(3):165-9. Available from: http://czasopisma.viamedica.pl/ait/article/vie w/19827

Smith AB, Hefley GC, Anand KJS. Parent Bed Spaces in the PICU: Effect on Parental Stress. 2007;33(3).

Frazier A, Frazier H, Warren $\mathrm{N}$ a. A Discussion of Family-Centered Care within the Pediatric intensive Care Unit. Crit Care Nurs Q [Internet]. 2010;33(1):82-6. Available from: http://www.ncbi.nlm.nih.gov/pubmed/20019 514

Bagnasco A, Calza S, Costa M, Rosa F, Sasso L. What Do Professionals Need for an OpenPaediatric Intensive Care Unit (PICU)? A focus Group Study on PICU Professionals. researchgate.net [Internet]. 2013 [cited 2015 Jan 20];1(1):31-8. Available from: http://www.researchgate.net/publication/256 436926_What_do_professionals_need_for_a n_Open-

Paediatric_Intensive_Care_Unit_(PICU)_A_ 
focus_group_study_on_PICU_professionals/ file/60b7d522884f27f7e3.pdf

Shields L, King SJ. Qualitative analysis of the care of children in hospital in four countries-Part 1. J Pediatr Nurs [Internet]. 2001 Apr [cited 2015 Apr 9];16(2):137-45. Available from: http://www.sciencedirect.com/science/article/ pii/S0882596301363832

Shields L, Nixon J. Hospital care of children in four countries. J Adv Nurs [Internet]. Department of Nursing and Midwifery, University of Limerick, Limerick, Ireland. linda.shields@ul.ie: Blackwell Scientific Publications; 2004 Mar;45(5):475-86. Available from: http://search.ebscohost.com/login.aspx?direct $=$ true $\& \mathrm{db}=$ mnh $\& \mathrm{AN}=15009350 \&$ site $=$ ehost live

Streubert HJ, Carpenter DR. Qualitative Research in Nursing Advancing the Humanistic Imperative. 3rd ed. Philadelphia: Lippincots Williams \& Wilkins; 2003.

Polit DF, Beck CT. Nursing Research Principles and Methods. 7th ed. Philadelphia: Lippincots Williams \& Wilkins; 2004.

Diaz-Caneja A, Gledhill J, Weaver T, Nadel S, Garralda E. A Child's Admission to Hospital: a Qualitative Study Examining the Experiences of Parents. Intensive Care Med [Internet]. 2005 Sep [cited 2014 Dec 1];31(9):1248-54. Available from: http://www.scopus.com/inward/record.url?ei $\mathrm{d}=2-\mathrm{s} 2.0$ -

25144500554\&partnerID=tZOtx3y1

Shudy M, de Almeida ML, Ly S, Landon C, Groft $\mathrm{S}$, Jenkins TL, et al. Impact of Pediatric Critical Illness and Injury on Families: A Systematic Literature Review. Pediatrics. 2006;118 Suppl(December):S203-18.

Latour JM, van Goudoever JB, Schuurman BE, Albers MJIJ, van Dam N a M, Dullaart E, et al. A Qualitative Study Exploring the Experiences of Parents of Children Admitted to Seven Dutch Pediatric Intensive Care Units. Intensive Care Med [Internet]. 2011;37:319-25. Available from: http://www.pubmedcentral.nih.gov/articleren der.fcgi?artid=3028069\&tool=pmcentrez\&re ndertype $=$ abstract

Colville G, Darkins J, Hesketh J, Bennett V, Alcock J, Noyes J. The Impact on Parents of A Child's Admission to Intensive Care: Integration of Qualitative Findings from A Cross-Sectional Study. Intensive Crit Care Nurs [Internet]. Newcastle: Elsevier Limited; 2009 Apr;25(2):72-9. Available from: http://search.proquest.com/docview/1034905 983? accountid=13771

Colville GA, Cream PR, Kerry SM. Do parents benefit from the offer of a follow-up appointment after their child's admission to intensive care?: an exploratory randomised controlled trial. Intensive Crit Care Nurs [Internet]. 2010 Jun [cited 2014 Dec 2];26(3):146-53. Available from: http://www.sciencedirect.com/science/article/ pii/S0964339710000194

Berube KM, Fothergill-Bourbonnais F, Thomas M, Moreau D. Parents' Experience of the Transition with their Child from a Pediatric Intensive Care Unit (PICU) to the Hospital Ward: Searching for Comfort Across Transitions. J Pediatr Nurs [Internet]. Elsevier Inc.; 2014;29(6):586-95. Available from:

http://dx.doi.org/10.1016/j.pedn.2014.06.001

Stuart M, Melling S. Understanding Nurses' and Parents' Perceptions of Family-Centred Care. Nurs Child Young People [Internet]. RCNi; 2014 Sep;26(7):16-20. Available from: http://search.ebscohost.com/login.aspx?direct $=$ true $\& \mathrm{db}=\mathrm{a} 9 \mathrm{~h} \& \mathrm{AN}=98012741 \&$ site $=$ ehost live

Ames KE, Rennick JE, Baillargeon S. A Qualitative Interpretive Study Exploring Parents' Perception of the Parental Role in the Paediatric Intensive Care Unit. Intensive Crit Care Nurs [Internet]. Newcastle: Elsevier Limited; 2011 Jun;27(3):143-50. Available from:

http://search.proquest.com/docview/1034907 825 ?accountid=13771

Dingeman RS, Mitchell E a., Meyer EC, Curley M a. Q. Parent Presence During Complex Invasive Procedures and Cardiopulmonary Resuscitation: A Systematic Review of the Literature. Pediatrics [Internet]. 2007;120:842-54. Available from: http://pediatrics.aappublications.org/cgi/doi/1 0.1542/peds.2006-3706

Melnyk BM, Alpert-Gillis L, Feinstein NF, Crean HF, Johnson J, Fairbanks E, et al. Creating Opportunities for Parent Empowerment: Program Effects on the Mental Health/Coping Outcomes of Critically Ill Young Children and their Mothers. Pediatrics. 2004;113(6):e597-607.

Just AC. Parent Participation in Care: Bridging the Gap in the Pediatric ICU. Newborn Infant Nurs Rev [Internet]. 2005 Dec [cited 2014 Dec 1];5(4):179-87. Available from: http://www.sciencedirect.com/science/article/ pii/S1527336905001534

Henderson DP, Knapp JF. Report of the National Consensus Conference on Family Presence During Pediatric Cardiopulmonary Resuscitation and Procedures. J Emerg Nurs [Internet]. Elsevier; 2006 Feb 2 [cited 2015 Feb 9];32(1):23-9. Available from: 
http://www.jenonline.org/article/S009917670 5007221/fulltext

Rennick JE, Lambert S, Childerhose J, CampbellYeo M, Filion F, Johnston CC. Mothers' Experiences of A Touch and Talk Nursing Intervention to Optimise Pain Management in the PICU: A Qualitative Descriptive Study. Intensive Crit Care Nurs [Internet]. Newcastle: Elsevier Limited; 2011 Jun;27(3):151-7. Available from: http://search.proquest.com/docview/1034907 818 ? accountid=13771

Meert KL, Clark J, Eggly S. Family-Centered Care in the Pediatric Intensive Care Unit. Pediatr Clin North Am [Internet]. 2013;60(3):76172. Available from: http://www.sciencedirect.com.ezproxy.ugm.a c.id/science/article/pii/S0031395513000254
Frazier a, Frazier H, Warren $\mathrm{N}$ a. A Discussion of Family-Centered Care within the Pediatric intensive Care Unit. Crit Care Nurs Q [Internet]. 2010;33(1):82-6. Available from: http://www.scopus.com/inward/record.url?ei $\mathrm{d}=2$-s2.074349100932\&partnerID=40\&md5=19baf79 e55ac0ee8cde85bc8dc025c0a

Maxton FJC. Parental Presence During Resuscitation in the PICU: The Parents' Experience: Sharing and Surviving the Resuscitation: A Phenomenological Study. J Clin Nurs. 2008;17:3168-76.

Thompson DR, Hamilton DK, Cadenhead CD, Swoboda SM, Schwindel SM, Anderson DC, et al. Guidelines for Intensive Care Unit Design*. Crit Care Med. 2012;40(5):1586600. 